\title{
THE LIFE HISTORY OF EPIDEMIC ENCEPHALITIS IN THE CHILD.*
}

BY

MARY M. STEVENSON, M.A., M.D.,

(From the Medical Department, Royal Hospital for Sick Children, Glasgow.)

Many accounts of epidemic encephalitis have already appeared, but few relate specially to children, and fewer still give a survey of a large series of cases during childhood observed over a long period. It is, therefore, hoped that the present account of the life history of the disease in the infant and child will not be without interest.

From 1918, the first year in which epidemic encephalitis was observed in (t)lasgow, till the early months of 1927, eighty-three examples of the disease were seen in the Royal Hospital for Sick Children, Glasgow. The first three of these were described by Professor Findlay ${ }^{1}$, in 1918; twenty-three were recorded in 1920 by Findlay and Shiskin ${ }^{2}$; and in 1923 the sequelæ as seen till 1921 in thirty-eight cases were described by Dr. Grace Anderson ${ }^{3}$.

These eighty-three cases have been traced and followed as far as possible during the last three years. The general position at present is as follows : Twelve deaths have occurred: four of these in the acute stage. Eight cases cannot be traced. There are therefore sixty-three cases known personally to the writer at the present time (August, 1927). In accordance with the findings in other series, the onset was most commonly in the first half of the year. 70 per cent. of the cases were males. Age had apparently little influence since cases appeared in every year from birth to thirteen years, although the disease was relatively more frequent in children over seven years. The youngest case was aged two months at the onset and three others were under one year.

Apart from the possible exceptions about to be mentioned there is no evidence of case-to-case infection in this series. In 1924, in the month of April, four cases were admitted who attended one school and three who attended another school. These seven cases formed 63 per cent. of all the acute cases admitted during that epidemic. No two, however, were in the same class at school and there was no evidence that any of the children had been in immediate contact.

\section{Counse of Disease.}

The course of the disease in these children has been fairly typical. No one case has presented all the symptoms observed. In the greater number, however, the picture when seen as a whole was characteristic. It was not always possible to diagnose the case with certainty in the acute stage, but the later stages when followed have made the diagnosis clear.

* Abstract of Thesis accepted for the degree of M.1D., Glasgow University. 
The course has, generally speaking, been as follows :-A child has suddenly become ill. Suddenness of onset has been very conspicuous in this series, being present in seventy-one of the eighty-three cases. Thus a child might go to school apparently normal and return two hours later extremely ill. The most frequent early symptoms were :-insomnia in 50 per cent, choreiform restlessness in 29 per cent, lethargy in 26 per cent, diplopia in 20.5 per cent, headache in 15 per cent, pain in $\mathbf{1 4}$ per cent. Other symptoms, such as vomiting, convulsions, etc., occurred much less often.

This sudden onset was followed by a period of acute illness which varied in length from a few days to two months. Fever was present for the first week or two ; the child was in some cases lethargic, in others wildly restless, or, it might be, restless for some days and then lethargic. Other symptoms such as respiratory disturbance, myoclonus, ocular disturbances, were also often present at this stage. On recovery from the acute illness there was usually a period of apparent return to health. This lasted from a few days to a month, but in every case was broken sooner or later by the appearance of new symptoms. The length of this latent period is evidently very variable : McAlpine ${ }^{4}$ describes an adult case in which there had been apparently good health for more than three years.

In every case in this series this period of apparent recovery was broken by the appearance of one or other of the later symptoms. Mentalchanges, nocturnal excitement, conduct changes, respiratory disturbances, the Parkinsonian syndrome, loss of accommodation, choreiform restlessness, myoclonic movements and obesity occurred in that order of frequency, nocturnal excitement usually appearing first. Two or more of these might be present simultaneously or they might appear in sequence. No two cases presented these symptoms in exactly the same way. The individual picture is therefore varied but the general history is characteristic.

\section{Signs and Symptoms.}

Fever.

This was usually present in the early stage. Thirty-eight cases were admitted to hospital in the first two weeks after onset, and of these thirty-one showed a rise of temperature. The remaining seven were admitted from nine days to two weeks after the onset. These may, therefore, have already passed through a febrile period, as the duration of fever is frequently only a week or less.

Table I shows the duration of fever in the cases which survived.

TABLE I.

DLRATION OF FEVER IN SLRTIVING ('ASES.

\begin{tabular}{ccccc}
\hline & Duration. & & & Cases. \\
\hline 1 week & $\ldots$ & $\ldots$ & $\ldots$ & 8 \\
12 weeks & $\ldots$ & $\ldots$ & $\ldots$ & 11 \\
$23,$, & $\ldots$ & $\ldots$ & $\ldots$ & 6 \\
$36,$, & $\ldots$ & $\ldots$ & $\ldots$ & 2 \\
\hline
\end{tabular}


The return to normal temperature was in every case earlier than the disappearance of other signs and symptoms : lethargy, for instance, commonly persisted for weeks after the disappearance of fever.

Except in fatal cases the temperature was never very high (Table II). In the four fatal cases the temperature before death was $101^{\circ}, 102 \cdot 6^{\circ}, 104^{\circ}$ and $108^{\circ}$. In one case followed by recovery the temperature rose to over $105^{\circ}$ for some hours during a series of convulsions.

TABLE II.

MAXIMUM TEMPERATURES.

\begin{tabular}{rcccc|c}
\multicolumn{7}{c|}{ Temperature. } & ('ases. \\
\hline $99-100$ & Fahr. & $\ldots$ & $\ldots$ & $\ldots$ & 3 \\
$100-101^{\circ}$ &, & $\ldots$ & $\ldots$ & $\ldots$ & 3 \\
$101-102$ & $\ldots$ & $\ldots$ & $\ldots$ & $\ldots$ & 4 \\
$102-103$ & $\ldots$ & $\ldots$ & $\ldots$ & $\ldots$ & 10 \\
$103-104$ &.. & $\ldots$ & $\ldots$ & $\ldots$ & 7 \\
$104-105$ &., & $\ldots$ & $\ldots$ & $\ldots$ & 2 \\
$105-106$ &,. & $\ldots$ & $\ldots$ & $\ldots$ & 1 \\
$108 \circ$ Fahr. .. & $\ldots$ & $\ldots$ & $\ldots$ & 1 \\
\end{tabular}

\section{Lethargy.}

Lethargy was present in fifty of the eighty-three cases during the acute stage. In twenty-three it was the first symptom noticed. In twenty the lethargy followed a preliminary period of choreiform restlessness of from two to ten days. This type of onset with chorea appeared for the first time in 1920, and also occurred very frequently during the epidemic of 1924.

The lethargy in far the greater number of cases lasted from 10 to 23 days. The outstanding exceptions were two cases where it only lasted for 12 and 24 hours respectively, and four where it persisted for 9, 10, 14 and 16 weeks. These variations, however, did not appear to influence later developments.

The lethargy varied in depth in different cases and at different times in the same case. In some instances the child was never in bed, but slept whenever he sat down. As a rule, however, he lay completely impassive though able in most cases to respond to questions. The appearance often gave a false impression of paresis especially of the facial muscles. Occasionally a real though transient paralysis was detected. Lethargy at times deepened into coma. When this was accompanied by a rise of temperature death always followed. When lethargy had persisted for some weeks intermissions occasionally appeared. Thus in one case, after ten weeks of lethargy, a distinct improvement appeared for two days, and was followed by six weeks' of drowsiness, not so deep as before.

Lethargy accompanied by fever has not been seen in the late stages. In two cases, however, there have been long periods of lethargy accompanied by obesity. In one both symptoms disappeared after about 18 months; in the other, both are still present four years after the onset of the illness. 


\section{Disturbances of the Motor System.}

Motor disturbances in this series can be classified thus: (1) Convulsions, only seen in the acute stage ; (2) Choreiform restlessness, occurring both early and late: (3) Myoclonus, which appeared in both the early and late stages and has remained for years; (4) Parkinsonian syndrome; occurring in late stages only.

(1) Convulsions. The onset of the disease was marked by convulsions in two cases. In one other (Case 79) the child had a series of convulsions with a temperature of $104^{\circ}$ on the fourth day of illness. This case later of the myoclonic type.

(2) Choreiform Restrlessness. This was a very prominent feature in 39 cases. It was noted by Findlay and Shiskin ${ }^{2}$ in 1920 and was found elsewhere at the same time. In 1924 it was a most characteristic feature of the epidemic.

The child suffering in this way is in a constant state of movement which ceases neither by night nor by day, and may indeed increase at night. Insomnia and a certain degree of delirium are present, though as a rule the child will answer questions fairly intelligently, and may even be able to control the movements for a moment or two.

In all but three cases, where it occurred first on the seventh day, this restlessness appeared as an early symptom. It lasted in most cases for from four to fourteen days, and in half the cases was followed by lethargy. In three atypical cases the chorea continued for one to two months, and in two others, where it was of a very violent description, it persisted for eighteen months and two years respectively, being accompanied by wild behaviour. Wimmer ${ }^{5}$ believes that it is impossible in the early stages to differentiate between this restlessness and that of rheumatic chorea. In the present series, however, the history of a sudden onset, the presence of ocular symptoms or of fever, were found to be reliable points in diagnosis. The restlessness is usually of a more extreme type than is observed in rheumatic chorea and shows, in contrast to rheumatic chorea, a tendency to increase during the night.

The later stages of the disease are sometimes also marked by choreiform restlessness: not, however, of the extreme type seen in the early stages. It consists of such movements as shrugging the shoulders, touching surrounding objects, or running round the room. These can be stopped for a considerable time if the child's attention is gained, but he is apparently unable to remain quiet otherwise. In one case such movements started in one leg and arm a vear after the onset of the illness but have in the last five vears become generalized.

(3) Mroclonus. In 1920, both Walshe ${ }^{6}$ and Sicard 7 reported cases which showed rhythmical contractions of the muscles. In the present series the first patient to show this symptom became ill in 1923. Altogether six examples of this type of the disease have been seen. Table III gives details of these : 
TABLE III.

MYOCLONIC CASES.

\begin{tabular}{|c|c|c|c|c|c|c|c|c|}
\hline $\begin{array}{l}\text { Case } \\
\text { No. }\end{array}$ & $\begin{array}{l}\text { Year of } \\
\text { acute } \\
\text { illness. }\end{array}$ & $\begin{array}{c}\text { Onset } \\
\text { of } \\
\text { Myoclonus. }\end{array}$ & Site. & $\begin{array}{c}\text { Rate } \\
\text { per } \\
\text { minute. }\end{array}$ & Pain. & Hyperpnœa. & $\begin{array}{c}\text { Present } \\
\text { state of } \\
\text { Myoclonus. }\end{array}$ & $\begin{array}{l}\text { General } \\
\text { condition. }\end{array}$ \\
\hline 52 & 1923 & 2nd week. & Respiratory. & 44 & $\begin{array}{l}\text { Abdominal : } \\
\text { general at } \\
\text { onset. }\end{array}$ & $\begin{array}{l}\text { Coinciding } \\
\text { in rate. }\end{array}$ & Lessening. & $\begin{array}{l}\text { Parkinsonian- } \\
\text { ism improv- } \\
\text { ing. }\end{array}$ \\
\hline 69 & 1924 & lst week. & $\begin{array}{l}\text { Extraordinary } \\
\text { muscles of res- } \\
\text { piration and arms. }\end{array}$ & 48 & $\begin{array}{l}\text { At onset in } \\
\text { arms. }\end{array}$ & ditto. & Lessening. & $\begin{array}{l}\text { Hyperpnœa. } \\
\text { Mentality } \\
\text { very poor. }\end{array}$ \\
\hline 79 & 1925 & lst week. & $\begin{array}{l}\text { Respiratory mus- } \\
\text { cles \& diaphragm. }\end{array}$ & 60 & None. & ditto. & $\begin{array}{l}\text { Lessening. } \\
\text { Still strong- } \\
\text { ly present } \\
\text { in sleep. }\end{array}$ & $\begin{array}{l}\text { Nocturnal ex- } \\
\text { citement. } \\
\text { Conduct very } \\
\text { bad. }\end{array}$ \\
\hline 70 & 1924 & 4th week. & $\begin{array}{lr}\text { Right side of } \\
\text { mouth } \\
\text { platysma. }\end{array}$ & 60 to 80 & None. & ditto. & Unchanged. & $\begin{array}{l}\text { Parkinsonian- } \\
\text { ism. }\end{array}$ \\
\hline 49 & 1923 & 24th month. & Left side of nose. & 50 & None. & $\begin{array}{l}\text { Not coin- } \\
\text { ciding. }\end{array}$ & Gone. & $\begin{array}{l}\text { Conduct bad. } \\
\text { Mentality } \\
\text { very poor. }\end{array}$ \\
\hline 71 & 1924 & 19th month. & $\begin{array}{l}\text { Right side of } \\
\text { mouth. }\end{array}$ & 44 & None. & - & $\begin{array}{l}\text { Marked. In } \\
\text { series of } 3 \\
\text { or } 4 \text { then } \\
\text { s } 1 \mathrm{i} \mathrm{g} \mathrm{t} \\
\text { pause. }\end{array}$ & $\begin{array}{l}\text { Mentality } \\
\text { poor. }\end{array}$ \\
\hline
\end{tabular}

The onset of myoclonus was in four of the six cases very early. In two it was one of the first signs observed. In all four it has persisted and has been as marked in the later stages as at the beginning. In another (Case 70) there was a variation from the usual course. This boy was admitted on the second day of illness in a state of choreiform excitement with a right-sided facial paresis. The paresis persisted till the fourth week, when a regular myoclonic twitch appeared in the same muscles. This remains after two years.

The sites of the myoclonic twitchings have been very similar, for three have affected the facial muscles and three the diaphragm and extraordinary muscles of respiration. The facial twitch in each case is unilateral. In the three cases where the respiratory muscles were affected it was and is strong enough to move the arms. In every case the twitch has remained confined to the original muscles affected.

The rate has been fairly constant in each case and has been peculiar to each. Thus in Case 70, quoted above, the contractions have been between 60 and 80 per minute for the last two years. In another (Case 71) the contractions occur in series of three or four and are about 40 per minute. This case and another (Case 49) where the contractions are not constantly present, are the two of late onset. Sleep has not lessened the contraction in any of these cases ; in Case 79, indeed, the contraction which has now almost disappeared by day is still very definite during sleep.

Association with pain. Marie and Levy ${ }^{9}$ mention cases in whom lancinating pain and fever at onset were succeeded by the appearance of short, rapid explosive muscular contractions. 
In one of this series (Case 69) the child complained first of pain in the hands which made him cry out. This was followed in a few hours by regular contractions of the thorax and arms. On the next day he was admitted to hospital with fever and myoclonic contractions of the muscles of the thorax and arms, which persisted for two years.

When the contractions affect the abdominal muscles the presence of pain may make diagnosis difficult. Hinds Howell ${ }^{10}$ reports a case which was diagnosed as appendicitis, and Stevenson ${ }^{11}$ records three sent to the Glasgow Royal Infirmary as acute abdominal cases. In the present series one child (Case .52) complained suddenly in February, 1923 of severe pain in the wrist, arm and back and next day in the abdomen. For one week she was treated as a case of acute rheumatism, when the diagnosis was changed to appendicitis. She was then admitted to a surgical ward but was transferred to a medical ward two days later. Twitching movements were present with pain but a few days later these were seen to be myoclonic in character. Hyperpnœa appeared ten days later. Eight months after the onset of illness she was again sent to the surgical wards as a case of appendicitis and once more transferred to the medical wards. The myoclonic contractions now coincided with respiration. Fever was again present with pain. In April, 1924, she was for a third time sent to the hospital with the diagnosis of appendicitis. Since then her condition has improved.

In no case has myoclonus been present alone in the later stages: other symptoms have invariably been present.

Prognosis. Myoclonus has been in this series very persistent. In four cases it appeared in the acute stage and is still present after one, two and three years. In three of these it is now much less marked, in the fourth it is unchanged after two years. As regards the two cases where it appeared first in the late stages, it is still present in one, but disappeared in the other after being present for only a few months.

(4) Parkinsonian Syndrome. Kennedy ${ }^{12}$ found that twenty-one out of fifty-nine children, seen by him on account of sequelæ, developed this syndrome. Of the seventy-three cases seen in the later stages of the illness in this series, twenty-two or $30 \cdot 2$ per cent. have shown some degree of Parkinsonianism. Fifty-five cases were seen in the first four months of illness and, of these, fourteen are now Parkinsonian in type.

Sex. Seventeen of the twenty-two children affected are boys.

Age. The ages at the time of the acute illness are seen in Table IV.

TABIE IV.

A(BE-INCIOEN('E IN PARKINSONIAN SYNIROME.

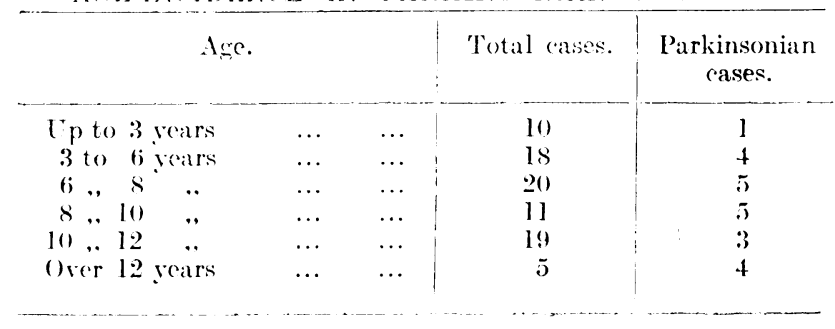


Our figures do not support Hall's suggestion ${ }^{8}$ that the syndrome appears more readily in the older patients.

Onset of the Parkinsonian Syndrome. Cases have been recorded by Hinds Howell ${ }^{10}$, Buzzard ${ }^{13}$ and others in which the syndrome appeared during the acute illness. This was never so in the present series. The period between recovery from the acute illness and the onset of Parkinsonianism was, however, in two cases very short. In neither of these was the normal animation fully recovered before the characteristic immobility became apparent, so that it is difficult to say when the syndrome really appeared. In a third, the first signs were also early, appearing three weeks after recovery from the acute illness. In six cases the period was between two and three years; and in one at least more than three years. These intervals were invariably bridged by the presence of other sequelæ.

Signs and Symptoms of the Parkinsonian Syndrome. Immobility of the face or of one limb was usually the earliest sign of the syndrome to be noticed. In all the twenty-two cases this has been present to some extent. In generalized cases the attitude is fixed and wooden in appearance. The child usually stands with the trunk bent forwards and elbows flexed. One child holds the trunk backwards, and two keep the head bent to one side with the trunk inclined towards the same side. The general appearance is in most cases unmistakeable. The gait is characteristic where the lower limbs are affected. The feet are hardly lifted from the ground, the steps are short. Well developed festination and retropulsion in this series are present, however, in only five cases.

As the syndrome advances, talipes equinovarus develops. This is present in all six of the most severe examples of the syndrome and in four of these it is bilateral. Some degree of slowness of movement is conspicuous in every case. In three of the older boys it is very pronounced. The phenomenon of sudden activity shown by an apparently immobile patient, named by Souques 14 "kinesia paradoxa," is present in four cases of the series. Cruchet"15 also describes such patients. The first child in whom this was observed in the present series is a boy who was acutely ill in 1920. He has since suffered from nocturnal excitement, hyperpnoea, and moral change, and is now a typical example of the Parkinsonian syndrome. His gait and attitude are in general remarkably wooden. On a sudden summons he has been seen by the present writer moving very rapidly, at a pace quite at variance with his usual extreme slowness.

Tremor has been present in eight of the twenty-two cases. In four of these, it is unilateral and is brought on by excitement or effort. After a moment it becomes of wide amplitude and irregular, and spreads to other limbs. In one case, in which the syndrome has now receded, the tremor was bilateral, increasing on effort, and much exaggerated at night. The third form of tremor affects all the limbs, is very fine and is constantly present. This is seen in two children. 
Voice.-In the more pronounced cases the voice has become high in pitch and monotonous in tone. Articulation tends to become slurring. This may be partially due to facial immobility but certainly varies, usually becoming more pronounced in the evening. This increase of Parkinsonianism with fatigue is emphasized by Sainton and Schulmann. ${ }^{16}$

Excessive salivation was present in all but two of the Parkinsonian cases. These children are usually seen with the lower jaw hanging, and saliva dribbling out of the mouth. Excess of saliva is present also in other types but in these it is usually associated with the act of spitting. One child has continued this habit for five years.

Table V gives details of the twenty-two case: :-

TABLE V.

PARKINSONIAN CASES.

\begin{tabular}{|c|c|c|c|c|c|c|c|c|}
\hline $\begin{array}{l}\text { Case } \\
\text { No. }\end{array}$ & Attitude. & Gait. & Speech. & Salivation & Tremor. & $\begin{array}{l}\text { Previous } \\
\text { sequelæ. }\end{array}$ & $\begin{array}{c}\text { Other } \\
\text { sequelæ now } \\
\text { present. }\end{array}$ & $\begin{array}{c}\text { General } \\
\text { condition. }\end{array}$ \\
\hline 23 & Typical & $\begin{array}{l}\text { Festination and } \\
\text { retropulsion. } \\
\text { Double equino- } \\
\text { varus. }\end{array}$ & $\begin{array}{l}\text { High, } \\
\text { slurring. }\end{array}$ & Excessive & Coarse. & $\begin{array}{l}\text { Nocturnal } \\
\text { restless- } \\
\text { ness. } \\
\text { Obesity. }\end{array}$ & None. & Very weak. \\
\hline 12 & , & $\begin{array}{l}\text { Double equino- } \\
\text { varus. }\end{array}$ & ", & ", & ," & $\begin{array}{l}\text { Nocturnal } \\
\text { restless- } \\
\text { ness. Con- } \\
\text { ductbad. }\end{array}$ & , & , \\
\hline 28 & , & $\begin{array}{l}\text { Festination. } \\
\text { Retropulsion. }\end{array}$ & , & ", & $"$ & Hyperpnoua & , & , \\
\hline 68 & , & $\begin{array}{ll}\text { Slow. Unilat- } & \text { Ural equino- } \\
\text { varus. } & \end{array}$ & Slurring. & , & , & None. & , & , \\
\hline 72 & , & Very rigid. & Slow. & , & None. & $\begin{array}{l}\text { Chorea. } \\
\text { Conduct } \\
\text { bad. }\end{array}$ & , & , \\
\hline 80 & , & , & Slurring. & , & Coarse. & $\begin{array}{l}\text { Nocturnal } \\
\text { restless- } \\
\text { ness. }\end{array}$ & , & ", \\
\hline 18 & , & $\begin{array}{ll}\begin{array}{c}\text { Rigid. } \\
\text { eral }\end{array} & \text { Unilat- } \\
\text { varus. } & \end{array}$ & ," & ," & , & $\begin{array}{l}\text { Noct. rest- } \\
\text { lessness } \\
\text { chorea. }\end{array}$ & ", & $\begin{array}{l}\text { Can walk } \\
\text { fairly well. }\end{array}$ \\
\hline 17 & , & $\begin{array}{l}\text { Festination. } \\
\text { Retropulsion. }\end{array}$ & $\begin{array}{l}\text { High, } \\
\text { slurring. }\end{array}$ & ", & , & $\begin{array}{l}\text { Nocturnal } \\
\text { restless- } \\
\text { ness. }\end{array}$ & , & , \\
\hline 62 & , & Festination. & Slow. & Normal. & None. & $\begin{array}{l}\text { Nocturnal } \\
\text { restless- } \\
\text { ness and } \\
\text { sniffing. }\end{array}$ & , & ," \\
\hline
\end{tabular}


TABLE V-continued.

PARKINSONIAN CASES-continued.

\begin{tabular}{|c|c|c|c|c|c|c|c|c|}
\hline Case. & Attitude. & Gait. & Speech. & Salivation & Tremor. & $\begin{array}{l}\text { Previous } \\
\text { sequelæ. }\end{array}$ & $\begin{array}{c}\text { Other } \\
\text { sequelæ now } \\
\text { present. }\end{array}$ & $\begin{array}{l}\text { General } \\
\text { condition. }\end{array}$ \\
\hline 33 & , & $\begin{array}{l}\text { Festination and } \\
\text { retropulsion. }\end{array}$ & Slurring. & , & , , & $\begin{array}{l}\text { Nocturnal } \\
\text { restless- } \\
\text { ness. Hy- } \\
\text { perpnœa. }\end{array}$ & $\begin{array}{l}\text { Hyper- } \\
\text { pnœa. }\end{array}$ & , \\
\hline 76 & , & $\begin{array}{l}\text { Immobile. } \\
\text { Drags one foot. }\end{array}$ & , & , , & , & $\begin{array}{l}\text { Noctumnal } \\
\text { restless- } \\
\text { ness. }\end{array}$ & None. & , \\
\hline 36 & , , & , , , & $\begin{array}{l}\text { High, } \\
\text { slurring. }\end{array}$ & , & Fine. & $\begin{array}{l}\text { Nocturnal } \\
\text { restless- } \\
\text { ness. Con- } \\
\text { duct bad. } \\
\text { Hyperp- } \\
\text { nœa. }\end{array}$ & ," & , \\
\hline 75 & , & , & Good. & , & None. & $\begin{array}{l}\text { Nocturnal } \\
\text { restless- } \\
\text { ness. }\end{array}$ & , , & , \\
\hline 4 & , , & Unaffected. & Slurring. & Excessive. & , & $\begin{array}{c}\text { Choreiform } \\
\text { restless- } \\
\text { ness. Hy- } \\
\text { perpnœa. }\end{array}$ & $\begin{array}{c}\text { Choreiform } \\
\text { restless- } \\
\text { ness. Hy- } \\
\text { perpnœa. }\end{array}$ & $\begin{array}{l}\text { Can walk } \\
\text { well. }\end{array}$ \\
\hline 74 & , & Rigid. & $\begin{array}{l}\text { High, } \\
\text { Varies } \\
\text { greatly. }\end{array}$ & Normal. & Fine. & $\begin{array}{l}\text { Nocturnal } \\
\text { restless- } \\
\text { ness. }\end{array}$ & None. & $\begin{array}{l}\text { Deterior- } \\
\text { ating. }\end{array}$ \\
\hline 70 & $\begin{array}{c}\text { Head to } \\
\text { one side. }\end{array}$ & , & Slurring. & Excessive. & Coarse. & $\begin{array}{l}\text { Nocturnal } \\
\text { restless- } \\
\text { ness. } \\
\text { Myoclonus. } \\
\text { Conduct } \\
\text { bad. }\end{array}$ & $\begin{array}{l}\text { Myoclonus. } \\
\text { Conduct } \\
\text { bad. }\end{array}$ & , \\
\hline 65 & Immobile. & , & $\begin{array}{l}\text { Unaffec- } \\
\text { ted. }\end{array}$ & , & None. & $\begin{array}{l}\text { Nocturnal } \\
\text { restless- } \\
\text { ness. Con- } \\
\text { duct bad. }\end{array}$ & $\begin{array}{l}\text { Nocturnal } \\
\text { restless- } \\
\text { ness. Con- } \\
\text { duct bad. }\end{array}$ & $\begin{array}{l}\text { Deterior- } \\
\text { ating. }\end{array}$ \\
\hline 52 & Typical. & Little affected. & $\begin{array}{l}\text { Slurring, } \\
\text { quick. }\end{array}$ & Normal. & , , & $\begin{array}{l}\text { Myoclonus. } \\
\text { Hyper- } \\
\text { pnœa. } \\
\text { Conduct } \\
\text { bad. }\end{array}$ & $\begin{array}{l}\text { Hyper- } \\
\text { pnæa } \\
\text { Myoclonus. }\end{array}$ & Improving. \\
\hline 11 & , & Immobile. & Indistinct & Excessive. & , & $\begin{array}{l}\text { Bad con- } \\
\text { duct. }\end{array}$ & $\begin{array}{l}\text { Cruel. } \\
\text { Violent. }\end{array}$ & $\begin{array}{l}\text { Deterior- } \\
\text { ating }\end{array}$ \\
\hline 73 & , & $\begin{array}{l}\text { Almost unaffec- } \\
\text { ted. }\end{array}$ & $\begin{array}{l}\text { Very in- } \\
\text { distinct } \\
\text { and } \\
\text { slurring. }\end{array}$ & $\begin{array}{l}\text { Very ex- } \\
\text { cessive. }\end{array}$ & $\begin{array}{l}\text { Coarse } \\
\text { at } \\
\text { night. }\end{array}$ & $\begin{array}{l}\text { Nocturnal } \\
\text { restless- } \\
\text { ness. Con- } \\
\text { duct bad. }\end{array}$ & $\begin{array}{l}\text { Bad con- } \\
\text { duct. }\end{array}$ & $\begin{array}{l}\text { Very much } \\
\text { better. }\end{array}$ \\
\hline 5l & $\begin{array}{l}\text { Slightly } \\
\text { immo- } \\
\text { bile. }\end{array}$ & , , & , & Excessive. & None. & $\begin{array}{l}\text { Nocturnal } \\
\text { restless- } \\
\text { ness. }\end{array}$ & , & Improving. \\
\hline 4 & , & , & , & , & , & $\begin{array}{l}\text { Mentally } \\
\text { deficient. }\end{array}$ & $\begin{array}{l}\text { Mentally } \\
\text { deficient. }\end{array}$ & , \\
\hline
\end{tabular}

The face was in all cases masklike. 
The greater number of those showing the most severe results have already passed through periods of bad behaviour, cruelty, filthy habits, etc.

Likeness to Progressive Lenticular Degeneration. The close resemblance between the picture of progressive lenticular degeneration and that of some of these cases is very striking. In four (Nos. 12, 17, 23 and 28) the general picture reminds one even more strongly of this disease than of paralysis agitans. The facial expression, vacant rather than mask-like, the open mouth, the facile smiles and depression which cross the face, the attitude in bed, the talipes equinovarus, and the high monotonous voice with the peculiar cry, are all extremely like to what is met with in Wilson's disease. The history of the acute illness in all, however, is typical of epidemic encephalitis and unlike lenticular degeneration : no case has presented any enlargement of the spleen. Rogers ${ }^{17}$, Piltz ${ }^{18}$, and Wimmer ${ }^{5}$ have all remarked on the similarity of the two conditions and have reported illustrative cases.

Prognosis in the Parkinsonian Syndrome. There have been no deaths among the children who developed this syndrome. Nevertheless the prognosis for the child seems to be worse in this than in the other sequelæ. At the present date the condition of these children is as follows :-

\begin{tabular}{|c|c|c|}
\hline Great improvement & $\ldots$ & One case. \\
\hline Slight improvement & . . & Two cases. \\
\hline Stationary $\quad \ldots$ & . & $\begin{array}{l}\text { Two cases, for } \\
\text { three years res] }\end{array}$ \\
\hline $\begin{array}{c}\text { Deteriorating after } \\
\text { period } \quad . \\
\text { Steadily progressive }\end{array}$ & $\begin{array}{c}\text { stationary } \\
\ldots\end{array}$ & $\begin{array}{l}\text { Three cases. } \\
\text { Fourteen cases. }\end{array}$ \\
\hline
\end{tabular}

Only three, or 14 per cent., have shown any signs of disappearance of the syndrome.

It appears impossible to find a relation between the early history of the case and the develcpment of Parkinsonianism. One of the cases (No. 73) had a short acute illness of about fourteen days and almost a fortnight later the face, attitude and gait assumed a very immobile aspect. The condition progressed rapidly with coarse tremor, salivation and inarticulate speech, all most marked at night. A year later improvement began and the boy became practically free of the syndrome. He has since, however, been violent and extremely restless with persistent nocturnal excitement, and when seen at the date of writing is again showing rigidity of one leg with a tendency to retropulsion.

In all the other cases in which the syndrome appeared with so much severity, the condition has been progressive.

Cruchet $^{15}$ concludes that improvement, when it occurs, does so where the syndrome has been of early onset. In these cases he finds it fairly often curable. Case 73, just quoted, appeared to support this opinion but the reappearance of rigidity contradicts it. Of the two who show slight improvement one, Case 52, presented none of the signs till ten months after the acute illness. In the other, the onset of the syndrome cannot be accurately timed. Two of the worst cases (Nos. 68 and 72) showed the first signs very early and have 
been rapidly progressive. Of the six who are now bedridden, the period between the acute illness and the onset of the syndrome varied between five months and two years.

\section{Ocular Signs and Symptoms.}

Since the first report of this disease by Economo ${ }^{19}$ in 1917 , ocular signs and symptoms have featured in all clinical records. Foster Moore ${ }^{20}$ found ocular paralyses in $\mathbf{7 5}$ per cent. of a series of ninety-seven cases.

In the present series, out of forty acute cases seen, twenty-nine or 74.5 per cent. showed some paralysis of the eye. For the greater part these paralyses appeared in the acute stage and were characterized, like the other paralyses met with in the disease, by their transient nature. The striking exception to this has been in paralysis of accommodation, which once being present has tended to remain and has often been a valuable aid in the diagnosis of a case coming under observation for the first time during the later stages of the disease.

Diplopia was complained of in nineteen cases, of which details are given in Table VI.

TABLE VI.

INCIDENCE OF DIPLOPIA.

\begin{tabular}{|c|c|c|}
\hline Number of cases. & Day of illness. & Duration. \\
\hline 14 & 1 st & 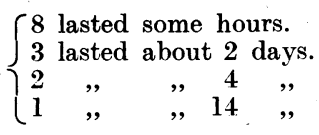 \\
\hline 2 & 2nd & $\left\{\begin{array}{ccc}1 & \text { lasted about } 1 & 1 \text { day. } \\
10, & 6 & \text { days. }\end{array}\right.$ \\
\hline 1 & $3 \mathrm{rd}$ & A few hours. \\
\hline 1 & 5 th & About 2 days. \\
\hline 1 & 5th month & About 2 days. \\
\hline
\end{tabular}

In one case (No. 23) diplopia recurred after some days. It followed on fifteen hours of amaurosis, and persisted for several days.

Except for one case in which it appeared in the fifth month, none of the children has ever complained of it in the later stages. It is interesting to note that in all cases where diplopia occurred it was followed by a period of excitement of varying duration.

Strabismus was present in eleven cases during the acute stage, usually in very transient form.

Ptosis was only found in eight cases, and in three of these was bilateral. This figure is low as compared with that of the Ministry of Health Report ${ }^{21}$ in which about half of the cases were stated to have been affected. In one of our cases ptosis persisted for several months. 
Nystagmus occurred in six cases during the acute stage and has been found occasionally in the later stages also.

Internal muscles of the eye. In eighteen of the eighty-four cases loss of the reflex on accommodation with retention of the light reflex has. occurred. In one other case accommodation has been sluggish. The following table gives the history of this paralysis in the cases in which it occurred.

TABLE VII.

REACTION ON ACCOMMODATION.

\begin{tabular}{|c|c|c|c|c|c|c|c|}
\hline \multirow{2}{*}{$\begin{array}{c}\text { Case } \\
\text { No. }\end{array}$} & \multirow{2}{*}{$\begin{array}{l}\text { Onset } \\
\text { of } \\
\text { illness. }\end{array}$} & \multirow{2}{*}{$\begin{array}{l}\text { Accommodation } \\
\text { during the } \\
\text { acute stage. }\end{array}$} & \multicolumn{5}{|c|}{ Accommodation after } \\
\hline & & & 1 year. & 2 years. & 3 years. & 4 years. & 5 years. \\
\hline 9 & 1918 & Lost 3rd week. & Present. & & $\ldots$ & $\ldots$ & Present. \\
\hline 11 & 1920 & Child not seen. & Lost. & Lost. & $\cdots$ & $\ldots$ & Not traced. \\
\hline 12 & , & Child not seen. & $\ldots$ & Lost. & $\ldots$ & $\ldots$ & Lost. \\
\hline 17 & , & Present. & Sluggish. & Lost. & $\ldots$ & $\ldots$ & $\ldots$ \\
\hline 32 & ," & Present. & Lost. & $\ldots$ & $\ldots$ & $\ldots$ & $\ldots$ \\
\hline 35 & , & Present. & Lost. & $\ldots$ & $\ldots$ & $\ldots$ & Not traced. \\
\hline 37 & , & Present. & $\ldots$ & $\ldots$ & Lost. & $\ldots$ & Lost. \\
\hline 36 & ,, & Lost. & $\ldots$ & $\ldots$ & $\ldots$ & $\ldots$ & Lost. \\
\hline 21 & & Lost. & Lost. & Lost. & $\ldots$ & Lost. & Lost. \\
\hline 41 & 1922 & Child not seen. & $\ldots$ & $\ldots$ & Lost. & $\ldots$ & $\ldots$ \\
\hline 42 & 1923 & Sluggish. & $\ldots$ & Lost. & $\ldots$ & $\ldots$ & $\ldots$ \\
\hline 44 & ,, & Child not seen. & Lost. & Lost. & & $\ldots$ & $\ldots$ \\
\hline 49 & , & Lost 2nd week. & Lost. & $\ldots$ & Lost. & $\ldots$ & $\ldots$ \\
\hline 52 & 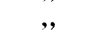 & Lost. & Present. & Present. & Present. & $\ldots$ & $\ldots$ \\
\hline 62 & 1924 & Child not seen. & Lost. & $\ldots$ & $\ldots$ & $\ldots$ & $\ldots$ \\
\hline 65 & ,, & Child not seen. & Lost. & $\ldots$ & $\ldots$ & $\ldots$ & $\ldots$ \\
\hline 75 & & Child not seen. & Lost. & $\ldots$ & $\ldots$ & $\ldots$ & $\ldots$ \\
\hline 79 & 1925 & Sluggish. & Sluggish. & $\ldots$ & $\ldots$ & $\ldots$ & $\ldots$ \\
\hline
\end{tabular}

It will be noticed that the reflex has returned in two cases. In both of these it was absent only for a short period during the acute stage. In all the others the condition has remained unchanged.

Boveri22 lays much stress on loss of accommodation with retention of the light reflex in this disease and considers it one of the last manifestations to disappear. Genet ${ }^{37}$ and Wimmer ${ }^{5}$ also regard it as an important diagnostic aid in cases seen long after the acute onset.

The Argyll-Robertson pupil was not seen in this series, except for a short time in Case No. 16.

Inequality of the pupils was present in four cases during the acute stage. All, after one, two and five years, are now normal. Seven cases first seen in the later stages had unequal pupils. Of these, four are now normal five years after their acute illness, and three are still unequal one, one and a half and five years afterwards.

Fundi. Changes are recorded by different writers. In the present series such changes are rather more than usually frequent : in most instances the results of the ophthalmological examination was confirmed by Dr. Maitland Ramsay.

In acute stages. Thirty-four of our forty acute cases were examined ophthalmoscopically. Twenty-one were normal. The findings in the other cases are shown in Table VIII :- 
TABLE VIII.

FUNDI IN ACUTE STAGE.

\begin{tabular}{|c|c|c|}
\hline Case & No. & Ophthalmoscopic appearances. \\
\hline Case & & "Dises slightly red and swollen-vessels engorged and tortuous." \\
\hline Case & & "Fulness of both dises with obscuration of the margins." \\
\hline Case & 23 & "Both fundi red and swollen with vessels obscured in places." \\
\hline Case & 47 & "Right disc distinctly pink." \\
\hline Case & 56 & $\begin{array}{l}\text { "Both discs congested-vessels full-margins obscured but slight cupping } \\
\text { in centre-left disk greyish in colour." }\end{array}$ \\
\hline Case & 49 & $\begin{array}{l}\text { lst week, " nil." 2nd week, "Pink discs-congested veins, whole fundus } \\
\text { red." }\end{array}$ \\
\hline C'ase & 51 & $\begin{array}{l}\text { "Pink discs and congested retinal veins. No sign of exudate in or around } \\
\text { disc." }\end{array}$ \\
\hline Case & 54 & $\begin{array}{l}\text { "Both optic discs pink in colour, but well defined. ,Veins turgid with greatly } \\
\text { increased calibre as compared with the arteries." }\end{array}$ \\
\hline Case & 53 & "Both discs slightly swollen." Week later, "nil." \\
\hline C'ase & 74 & $\begin{array}{l}\text { "General appearance of right fundus is considerably more congested than } \\
\text { that of the left. The appearance of the right is that associated with } \\
\text { encephalitis." }\end{array}$ \\
\hline Case & 71 & $\begin{array}{l}\text { "Increased tortuousity of retinal veins in left eye as compared with the } \\
\text { right. Otherwise the fundi are normal." }\end{array}$ \\
\hline Case & 67 & "Discs red and slightly full. Margins obscured." \\
\hline Case & 78 & "General hyperæmia." \\
\hline
\end{tabular}

In later stages. Thirty cases were examined two months or longer after the acute stage. Of these twenty-two were normal : the abnormal conditions in the remainder are shown in Table IX.

TABLE IX.

FUNDI IN LATE STAGE.

\begin{tabular}{|c|c|c|}
\hline ('ase No. & Interval. & Ophthalmoscopic appearances. \\
\hline Case 15 & 3 months & $\begin{array}{l}\text { "Congestion of fundi of both eyes but nothing abnormal in the } \\
\text { disc." }\end{array}$ \\
\hline ( ase 23 & 3 months & "Veins enlarged. Slight swelling of discs." \\
\hline ( ase 16 & ti months & $\begin{array}{l}\text { Fundus in both eyes is abnormally red in colour. The optic } \\
\text { discs are congested, and the red colour of the disc merges with } \\
\text { the general red of the fundus so that its outline is obscured.; } \\
\text { The retinal veins are swollen and the light reflex is absent." }\end{array}$ \\
\hline ( ase 63 & 8 months & "Right disc slightly swollen on temporal side, otherwise nil." \\
\hline ('ase 12 & 9 months & "Dises well defined. Fundi unduly red." \\
\hline ('ase 38 & 1 vear... & $\begin{array}{l}\text { " Discs very pale-vessels small-optic atrophy." Died six } \\
\text { days later. }\end{array}$ \\
\hline Case 45 & 1 year $\ldots$ & $\begin{array}{l}\text { "Discs are congested but both congenital cup and margins are } \\
\text { well defined. Veins are greatly congested and the calibre of } \\
\text { the arteries is increased." }\end{array}$ \\
\hline Case 19 & $2 \%$ years & $\begin{array}{l}\text { "General hyperæmia of whole fundus more marked on left } \\
\text { side than on the right. Veins congested." }\end{array}$ \\
\hline
\end{tabular}

\section{Paralysis.}

The most frequent paralysis seen, after those of the eye, was that of the seventh cranial nerve. This occurred in seven of the thirty-eight cases and was always transient.

In six cases there were transient paralyses of the limbs. In one, however, a definite hemiplegia developed after recovery from lethargy, in the fifth week of illness. This persisted till death, which took place during the eleventh week of illness, 
One child still shows a paralysis affecting the lower right half of the face. This developed about a year after the onset of illness and still persists after five years.

\section{Reflexes.}

The knee-jerks were increased in the majority of cases in both the early and late stages. Ankle clonus was present in four cases during the acute stage and in one during the later stages. An extensor plantar response was present in four cases during the acute stage. In three it was transient; in one it remained till death. In two cases, both of the Parkinsonian type, the extensor response appeared first during the later stages.

Pain.

In twenty-three cases pain of a severe neuralgic character was present during the early stages of the disease. In ten of these the pain took the form of headache, in nine it was situated in the limbs, in six in the abdomen and in one in the nose.

In most cases the site of the pain varied from day to day and physical examination revealed nothing abnormal. In the early stages sometimes caused difficulty in the differentiation of encephalitis from rheumatic fever and acute abdominal conditions (cf. Case 52, quoted above). In each case of headache in the early stages, lethargy followed. Pain in the other situations was always followed by some form of hyperkinesis.

Pain in the later stages has only been noted in four cases. In one it was followed by hemiplegia and death; in another by slight atrophy of the affected muscles; in the third a flitting pain was frequently present in the muscles of the limbs for about two years.

Cerebro-spinal fuid.

In sixty-seven cases the cerebro-spinal fluid was examined. In 1920 Prof. Findlay and Dr. Shiskin ${ }^{2}$ gave a full report of twenty-four of these. Since then the examination has been continued in the same way, and the following remarks apply to the total number.

The fluid in the majority of cases was under increased pressure and clear ; in one or two cases, not included here, it was blood-stained. Pandy's test was invariably negative.

Cytological examination usually showed a slight increase in the number of cells during the acute stage, estimating five cells per c.mm. as the maximum normal figure. During the first three months the figures 30, 20, 10 were common, although in one case during the tenth week only two cells were found. Increase in cells was also found by Boveri ${ }^{23}$ and Symonds ${ }^{24}$, the latter of whom found a number varying up to 50 or even 100 . In the later stages the number of cells was normal except in two cases, where at the end of one year the cells numbered seven per c.mm. The increase in cells was found in every case to be due to an increase of lymphocytes.

Since 1920, the colloidal gold test of Lange has been carried out as a routine on these fluids. The results of seventy-five tests on sixty children are shown in Table $\mathrm{X}$, 
TABLE X.

COLLOIDAL GOLD TESTS.

\begin{tabular}{|c|c|c|c|c|}
\hline 39 ('ases in acute stage & $\left\{\begin{array}{l}\text { Positive in } \ldots . \\
\text { Faintly positive in } \\
\text { Negative in } \ldots\end{array}\right.$ & $\begin{array}{l}\cdots \\
\cdots \\
\cdots\end{array}$ & $\begin{array}{r}21 \\
8 \\
10\end{array}$ & $\left.\begin{array}{l}52 \% \\
21 \% \\
26 \%\end{array}\right\} 73^{\circ} \%$ \\
\hline $\begin{array}{l}26 \text { Cases between } 2 \text { months } \\
\text { and } 1 \text { year after onset } \ldots\end{array}$ & $\left\{\begin{array}{l}\text { Positive in } \\
\text { Faintly positive in } \\
\text { Negative in } \quad \ldots\end{array}\right.$ & $\begin{array}{l}\cdots \\
\cdots \\
\cdots\end{array}$ & $\begin{array}{r}12 \\
7 \\
7\end{array}$ & $\left.\begin{array}{l}+2 \% \\
29 \% \\
29 \%\end{array}\right\} 71 \%$ \\
\hline $\begin{array}{l}9 \text { Cases between } 1 \text { and } 3 \text { years } \\
\text { after onset } \quad \ldots\end{array}$ & $\left\{\begin{array}{l}\text { Positive in } \\
\text { Faintly positive } \ldots \\
\text { Negative in }\end{array}\right.$ & $\begin{array}{l}\cdots \\
\cdots \\
\cdots\end{array}$ & $\begin{array}{l}1 \\
2 \\
6\end{array}$ & $\left.\begin{array}{l}11 \% \\
22 \% \\
66 \%\end{array}\right\} 33^{\circ} \%$ \\
\hline
\end{tabular}

The cases in whom we had the opportunity to repeat the test gave the following results :-

TABLE XI.

COLLOIDAL GOLD TESTS REPEATED AT INTERVALS.

\begin{tabular}{|c|c|c|c|c|c|}
\hline Case No. & \multicolumn{3}{|c|}{ Period of illness. } & Colloidal gold test. & Remarks. \\
\hline 38 & $\begin{array}{l}\text { 1st week } \\
\text { 3rd week }\end{array}$ & $\begin{array}{l}\cdots \\
\cdots\end{array}$ & $\begin{array}{l}\cdots \\
\cdots\end{array}$ & $\begin{array}{l}00000000000 \\
55555432000\end{array}$ & Died in 13th month. \\
\hline 32 & $\begin{array}{l}\text { 2nd week } \\
\text { 4th week } \\
\text { 3rd month }\end{array}$ & $\begin{array}{l}\ldots \\
\cdots \\
\cdots\end{array}$ & $\begin{array}{l}\cdots \\
\cdots \\
\cdots\end{array}$ & $\begin{array}{l}11232200000 \\
01221000000 \\
12331000000\end{array}$ & Parkinsonianism. \\
\hline 37 & $\begin{array}{l}2 \text { nd week } \\
3 \text { years }\end{array}$ & $\begin{array}{l}\cdots \\
\cdots\end{array}$ & $\begin{array}{l}\cdots \\
\cdots\end{array}$ & $\begin{array}{l}01211000000 \\
00000000000\end{array}$ & Mentally defective. \\
\hline 31 & $\begin{array}{l}\text { 3rd week } \\
9 \text { th week }\end{array}$ & $\begin{array}{l}\cdots \\
\cdots\end{array}$ & $\begin{array}{l}\cdots \\
\cdots\end{array}$ & $\begin{array}{l}01121100000 \\
12221100000\end{array}$ & Mentally defective. \\
\hline 52 & $\begin{array}{l}\text { 2nd week } \\
\text { 4th week }\end{array}$ & $\begin{array}{l}\cdots \\
\cdots\end{array}$ & $\begin{array}{l}\cdots \\
\cdots\end{array}$ & $\begin{array}{l}00000000000 \\
23444310000\end{array}$ & Parkinsonianism. \\
\hline 51 & $\begin{array}{l}\text { lst week } \\
\text { 13th week }\end{array}$ & $\begin{array}{l}\cdots \\
\cdots\end{array}$ & $\begin{array}{l}\cdots \\
\cdots\end{array}$ & $\begin{array}{l}01232100000 \\
12223210000\end{array}$ & Mentally very poor. \\
\hline 68 & $\begin{array}{l}\text { lst week } \\
13 \text { th week } \\
1 \text { year }\end{array}$ & $\begin{array}{l}\cdots \\
\cdots \\
\cdots\end{array}$ & $\begin{array}{l}\cdots \\
\cdots \\
\cdots\end{array}$ & $\begin{array}{l}00000000000 \\
22341000000 \\
00121000000\end{array}$ & Parkinsonianism. \\
\hline 72 & $\begin{array}{l}\text { 2nd week } \\
\text { 17th week }\end{array}$ & $\begin{array}{l}\ldots \\
\cdots\end{array}$ & $\begin{array}{l}\cdots \\
\cdots\end{array}$ & $\begin{array}{l}01355420000 \\
01232210000\end{array}$ & Parkinsonianism. \\
\hline
\end{tabular}

The test is therefore usually positive during the acute stage, although during the first week it is occasionally negative. After the acute stage is past it again becomes negative. This test is undoubtedly valuable when positive during the earlier months of the disease, but may be negative even when clinical signs are very striking. The Wassermann test in all the cases cited was negative.

The fluid was cultured in about one-third of the cases. A growth of Gram-negative diplococci was obtained in one, but in that fluid contamination was suspected, 


\section{Nocturnal Excitement.}

Nocturnal excitement has assumed a very prominent position in the sequelæ seen in this series. Findlay and Shiskin"2, and later Anderson ${ }^{3}$, described it in detail and since then it has been mentioned by all observers dealing with children. Kennedy ${ }^{12}$, for example, found it in nineteen out of twenty-one children. In the present series, sixty-one out of seventy-three cases seen in the later stages suffered from it.

The course of events is now well known. As evening approaches, the child becomes more and more talkative and noisy, occasionally even violent. Other sequelæ which may be simultaneously present, e.g., hyperpnoca, become more marked during the wakeful hours. Almost invariably the child is anxious to sleep and tries by every arrangement of the bed to encompass this end, but without effect, until at about 5 or 6 a.m. he falls asleep and remains so till the next afternoon.

The inversion of the sleep rhythm in the present series usually followed on fairly rapidly, recovery from the acute illness. The average time from the onset of the acute illness was about ten weeks, though occasionally it appeared in the third week of illness, and in one case was delayed until three years afterwards. In four cases nocturnal excitement with sleep by day was the first sign of illness noticed (Table XII).

TABLE XII.

CASES IN WHICH INVERSION OF THE SLEEP RHYTHM

- WAS THE FIRST SIGN.

\begin{tabular}{c|c|c}
\hline Case No. & Duration of N.R. & Present condition. \\
\hline 14 & $2 \frac{1}{2}$ years & Very backward. Mental ratio 57. \\
44 & $2 \frac{1}{2}$ years & $\begin{array}{c}\text { Hyperpnœa, loss of accommodation, mentally back- } \\
\text { ward. Mental ratio } 67 .\end{array}$ \\
47 & $2 \frac{1}{2}$ years & $\begin{array}{c}\text { Nocturnal restlessness still present. Bard tempered, } \\
\text { quarrelsome. Mental ratio 89. } \\
\text { Choreiform restlessness. mentally backward. Mental } \\
\text { ratio 80. }\end{array}$ \\
\hline
\end{tabular}

In these four cases there was no history of an acute attack. In one or two others, however, further investigation of the history disclosed facts suggestive of an acute onset. Thus, in one case, the child was found to have been operated on for appendicitis two months earlier: on enquiry it was discovered that operation had not shown definite inflammation of the appendix and that the boy had been very drowsy during the illness. It seems probable that this was one of those cases with abdominal pain as an early symptom. In another an illness three months earlier, showing drowsiness and fever, had been diagnosed as pneumonia. Judging from the difficulty in obtaining these facts, it seems probable that in the other cases a slight preliminary illness may have been overlooked, 
The psychic element in night restlessness is very evident. Change of surroundings frequently produces normal sleep for a night or two, even a change from one ward to another having this effect. Dr. Anderson found injections of sterile water successful in one case until the patient discovered the nature of the fluid injected.

The onset of fever restores the normal sleep rhythm. This was observed during intercurrent febrile attacks (measles and mumps). In two cases the present writer injected vaccine intravenously. Normal sleep accompanied the subsequent fever but reverted to the abnormal rhythm at once on its disappearance.

TABLE XIII.

RESPIRATORY DISTURBANCES.

\begin{tabular}{|c|c|c|c|c|}
\hline Case. & $\begin{array}{l}\text { Original respiratory } \\
\text { abnormality. }\end{array}$ & $\begin{array}{l}\text { Period at } \\
\text { which } \\
\text { disturbance } \\
\text { appeared. }\end{array}$ & $\begin{array}{c}\text { Duration since } \\
\text { onset of } \\
\text { disturbance } \\
\text { to present. }\end{array}$ & $\begin{array}{c}\text { State of respiratory } \\
\text { abnormalities at present. }\end{array}$ \\
\hline 8 & Panting attacks & 2nd year & 5 years & Present occasionally. \\
\hline 10 & Panting attacks & 4th week & 6 years & Present less frequent. \\
\hline 11 & Panting attacks & 3rd year & $3 \frac{1}{2}$ years & Present occasionally. \\
\hline 13 & Panting attacks & 7 th month & 5 years & Gone. \\
\hline 14 & Panting attacks $\quad \ldots$ & 3rd year & 4 years & Gone. \\
\hline 16 & Sighing, smacking lips. & 2nd year & 4 years & Gone. \\
\hline 19 & Panting attacks & 6 th week & 5 years & Less frequent. \\
\hline 20 & Panting attacks & 2nd year & 4 years & Gone. \\
\hline 21 & $\begin{array}{l}\text { Panting attacks } \\
\text { Clearing throat }\end{array}$ & 3rd year & $4 \frac{1}{2}$ years & Present. \\
\hline 24 & Grunting noises & 2nd year & Not traced & - \\
\hline 25 & $\begin{array}{l}\text { Panting attacks } \\
\text { Blowing down nose }\end{array}$ & 2nd year & $4 \frac{1}{2}$ years & Gone. \\
\hline 28 & Panting attaeks $\quad .$. & 14th month & $4 \frac{1}{2}$ years & Gone. \\
\hline 29 & Panting attacks & 2nd year & 4 years & Less frequent. \\
\hline 32 & Panting attacks & 3rd year & Not traced & - \\
\hline 33 & Panting attacks & 2nd year & 4 years & Unchanged. \\
\hline 36 & Panting attacks & 3rd year & 3 years & Improving. \\
\hline 40 & Panting attacks & 3rd month & Not traced & - \\
\hline 41 & $\begin{array}{l}\text { Panting attacks } \\
\text { Apnœa }\end{array}$ & lst year & 2 years & Present. \\
\hline 44 & Panting attacks & 2nd year & 1 year & Occasional. \\
\hline 46 & Panting attacks $\quad \ldots$ & lst year & 2 years & Unchanged. \\
\hline $4 !$ & $\begin{array}{l}\text { Continual rapid res-... } \\
\text { piration. } \\
\text { Panting attacks }\end{array}$ & Acute attack & $2 \frac{1}{2}$ years & Present. \\
\hline 52 & $\begin{array}{l}\text { Continual rapid res-... } \\
\text { piration. } \\
\text { Panting attacks }\end{array}$ & 2nd week & $2 \frac{1}{2}$ years & $\begin{array}{l}\text { Present, improving. } \\
\text { Myoclonus of resp. } \\
\text { muscles. }\end{array}$ \\
\hline 57 & Panting attacks $\quad \ldots$ & lst year & 2 years & Occasional. \\
\hline 59 & Blowing nose, sniffing. & 3rd month & $1 \frac{1}{2}$ years & $\begin{array}{l}\text { Present. } \\
\text { Present. Apnœa now }\end{array}$ \\
\hline 60 & Panting attacks & 2nd month & $1 \frac{1}{2}$ years & $\begin{array}{l}\text { present. Violent } \\
\text { conduct during at- } \\
\text { tacks. }\end{array}$ \\
\hline 62 & Sniffing. blowing nose. & lst month & $1 \frac{1}{2}$ years & Present. \\
\hline 67 & Panting attacks $\ldots$ & lst year & 1 year & Present. \\
\hline 69 & $\begin{array}{l}\text { Continuous rapid... } \\
\text { respiration. } \\
\text { Panting attacks }\end{array}$ & 2nd week & $1 \frac{1}{2}$ years & $\begin{array}{l}\text { Present. } \\
\text { Myoclonus } \\
\text { muscles. }\end{array}$ \\
\hline 79 & Panting attacks & lst month & 一 & Present. \\
\hline
\end{tabular}


Duration. The duration of this nocturnal excitement with sleep by day varied in this series from one month to five years. The average duration was about eighteen months.

This is not one of the most permanent sequels but it is one of the most difficult to manage, either at home or in hospital.

\section{Disturbances of Respiration.}

Disturbances of respiration form one of the sequels found by practically all observers of this disease. Goodheart and Cottrell ${ }^{25}$, Levy ${ }^{26}$ and others describe a respiratory type of the disease. Kennedy ${ }^{12}$ found such disturbances in twenty out of fifty-one cases, Levy ${ }^{26}$ in ten out of one hundred and twentynine, Hinds Howell ${ }^{27}$ in three out of twenty-eight. In the present series these changes have been present in twenty-nine of the seventy-three cases seen in the later stages. Details of these are given in Table XIII.

In considering these cases, the classification used by Marie, Binet and Levy ${ }^{28}$ has been used. These observers divided the disturbances into three classes :-

(a) Respiratory troubles properly speaking.

(b) Phenomena of spasmodic cough.

(c) Manifestations of the nature of respiratory tics.

In the present series, there have been no cases suffering from spasmodic cough but of the twenty-nine cases, twenty-three belong wholly to the first class, two to the third and three have shown manifestations of both.

Derangements of respiration which occurred in the present series are as follow : (1)Attacks of rapid and noisy breathing ; (2) Continuous rapid breathing with occasional attacks of noisy respiration; (3) Apnœa. To these Marie, Binet and Levy ${ }^{28}$ add bradypnoa, which they found in one case. Wimmer ${ }^{5}$ found that this occurred seldom and in the present series it has never been observed.

(1) Attacks of rapid and noisy breathing form the most common respiratory disturbance and may appear hourly. They begin without warning and with no apparent cause. If the child is suffering from night restlessness, the attacks are much more frequent and severe by night. If sleep is normal, excitement of any kind appears to encourage an attack.

In all cases but one the children showed little disturbance during the attack, though one or two seemed restless while it lasted. The exception is formed by a boy of 10 years of age (Case 60) who between attacks is a quiet child and is becoming more and more passive in his general behaviour. About every 20 or 30 minutes rapid noisy respiration begins without any warning. It is accompanied by very violent behaviour in which he may break windows, tear clothing, or rush wildly out of any place or vehicle in which he may be. After some minutes there is a period of apnoa which lasts for about a minute. In this his face becomes blue, and latterly conscious is lost. He then resumes his former normal appearance and behaviour. He is very intelligent and has a mental ratio of 102 , but owing to the violence of his behaviour cannot be kept at school. This coincidence of violence or hyperkinesis with 
the disturbance of respiration was present in the majority of Kennedy's ${ }^{12}$ series and is considered by him very characteristic. In our series, however, the case mentioned is the single example and he has only developed it within the last eighteen months.

(2) Only four cases (Nos. 49, 52, 69, 79) have shown a continuous increase in the respiration rate. In these it maintained a rate of 40 to 60 a minute. In two it is still present after periods of one and a half and two years. It appears to cause little or no inconvenience to the children though in one (No. 49) it causes speech to be staccato and indistinct. In the other three it might easily pass unobserved. In one (No. 52) this rate was originally broken by attacks of noisy breathing. These have now, after two and a half years, disappeared and the rate of the respiration has fallen almost to normal.

In one case (No. 49) after three months of continuous hyperpnœa, with a respiration-rate of 50 to 80 per minute, there developed a tendency to tetany as shown by facial irritability, cyanosis and a fall in blood calcium.

In three cases (Nos. 52, 69 and 79) respiration corresponded with a myoclonic twitch of the diaphragm and extraordinary muscles of respiration.

(3) Periods of apnœa occurred in two cases, always at the end of an attack of noisy breathing. One (Case 60) has been quoted above. The other (Case 41) is a marked example of the Parkinsonian syndrome. The hyperpnoeic attacks occur almost every half hour and are very frequent during examination. At the end of each there is a period of about half a minute during which the child does not breathe and the face becomes extremely cyanosed. She responds faintly to requests during this period, which is ended by a cough and return to her usual appearance and behaviour.

Respiratory tics, such as a constant clearing of the throat, nose-blowing and sniffing, are present in several cases and like many of the other signs in the disease are most marked by night. One boy, aged 10 years (Case 59), was in hospital for months suffering from nocturnal restlessness which followed immediately upon the acute illness. During the whole of his stay, he blew his nose and sniffed loudly almost without cessation from about 5 p.m. till 4 or 5 a.m. His recovery appears at present to be exceedingly good, but after two years he still sniffs very frequently.

The onset of the respiratory disturbance occurred in eight cases during the first two months of illness. In twenty-one it appeared after intervals of from three months to three years. In the majority of cases it has therefore been a late manifestation. The duration was always long in this series, the shortest period being two and a half years. In one case the disturbance still remains after six years.

Prognosis. The tendency of these respiratory abnormalities appears to be towards disappearance. Three of the twenty-nine cases cannot be traced, but of the remaining twenty-six respiration is now normal in six, and improved in ten. Of the ten unchanged, the onset of illness in six was in the years 1924-25, so that they are still recent. . In some of the cases in which the disturbance has disappeared it existed in the most marked degree for long periods. 


\section{Mental changes in later stages.}

Shrubsall ${ }^{29}$ found, on examining London school children who had suffered from this disease, that the attention to school work and the value of the response steadily improved in most cases. This is very much more hopeful than the results in the present series of cases.

At the present time the mental state of the children in this series is, with only five exceptions, much below the average standard for their ages. It is extremely difficult to form an estimate of any value from ordinary observation. Parkinsonian cases from their expressionless faces and general slowness give an unduly bad impression, while many of the others from lack of natural shyness and reserve have an equally deceptive air of mental alertness. Both of these impressions are found on closer and longer observation to be erroneous.

In the effort to attain some definite idea of the mental capacity of children suffering from epidemic encephalitis, we were fortunate in having the assistance in the early cases of the late Dr. Watt and in the more recent years of Mr. Conn, from the Psychological Department of the University of Glasgow: The mental age and ratio were estimated by them while the children were in hospital. Mr. Conn has repeated the test in many of the children whom it has been possible to trace. The full results of these tests with further investigations have been published by Dawson and Conn ${ }^{30}$. Forty-six children of the series were tested and the mean of their mental ratio was found to be 87.73. The average intelligence of these was therefore significantly lower than that of nine hundred and seventy-four other hospital patients $(90 \cdot 53)$, and of their brothers and sisters (96.00). Thirty were re-tested at intervals varying from seven to thirty-six months, and the mean of their mental ratio was found to have dropped to $76 \cdot 13$. It was also found that the intelligence of the patients whose illness had lasted over twelve months was significantly lower than that of those whose illness was of shorter duration.

Hall $^{31}$, Paterson and Spence ${ }^{32}$ and others believe that the younger the child at the time of the acute illness the greater is the degree of mental deficiency. That is certainly true in this series. Twenty were under five years at the onset of illness. Of these five have not been traced, two are apparently normal at present, nine are of very poor intelligence and four have died imbecile. In these very young children, affected before their mentality is developed much, arrest of development is necessarily particularly grave.

The results of mental tests show no difference between Parkinsonian cases, those who have shown changes in conduct, and the other varieties of the disease. All deteriorate equally. This is interesting since the general appearance in Parkinsonian cases and in those showing conduct changes is apt to give a wrong impression. One child in this series is, however, an exception. He is a boy who during attacks of hyperpnoa is most violent in conduct, but has a mental ratio of 102 and takes a good place in school.

('hange in Conduct.

Many gradations of change in behaviour are present in this series. Some children, formerly docile, have become disobedient and unruly. Others have 
most violent tendencies. The most common observation of the parents is that the child has "completely changed his nature." In this series forty-six out of the seventy-three cases seen in later stages showed a definite deterioration in conduct, shown as follows :-

lrritability, bad temper and violence ; Destructiveness ; Cruelty to children and animals; Untruthfulness; Dirty habits ; Thieving, and sexual precocity.

Of these the first four have been by far the most frequent.

In many of the children, sudden outbursts of temper are frequent; in them they throw about dishes, knives, or anything within reach. Thieving has been common in five cases. In these, the thefts have been continual but never with intent to retain the stolen property. None makes any attempt to conceal the theft. All have been repeatedly punished by their parents with no effect. One, however, has now ceased the habit after a long time.

Many of the children become cruel. One boy cannot be left alone with his younger brothers for a moment on this account.

Details of these cases are contained in Table XIV.

TABLE XIV.

CHANGE OF CONDUCT.

\begin{tabular}{|c|c|c|c|c|c|}
\hline Case. & $\begin{array}{l}\text { Year of } \\
\text { acute } \\
\text { illness. }\end{array}$ & Change in behaviour. & $\begin{array}{c}\text { Conduct } \\
\text { at } \\
\text { present. }\end{array}$ & $\begin{array}{l}\text { Mental } \\
\text { ratio. }\end{array}$ & General condition. \\
\hline 5 & 1918 & $\begin{array}{l}\text { Destructive, dirty, unman- } \\
\text { ageable. }\end{array}$ & Very good. & - & Very backward \\
\hline 7 & 1919 & Violent temper, cruel. & Unchanged. & 71 & ,", \\
\hline 8 & ", & $\begin{array}{l}\text { Scratching, biting, vicious in } \\
\text { temper. }\end{array}$ & Docile. & 53 & , \\
\hline 9 & & Destructive, unmanageable. & Obedient, quiet. & - & "' \\
\hline 10 & & Vicious, destructive, violent. & Improved. & - & ,", \\
\hline 11 & 1920 & Treacherous, cruel. & Unchanged. & - & Parkinsonian. \\
\hline 12 & , & $\begin{array}{l}\text { Unmanageable, violent tem- } \\
\text { per. }\end{array}$ & Much improved. & - & " \\
\hline $\begin{array}{l}13 \\
14\end{array}$ & ”, & Destructive. & Improved. & 74 & Very backward. \\
\hline 15 & ", & $\begin{array}{l}\text { Deceptive, violent, cruel, de- } \\
\text { structive. }\end{array}$ & & - & $\begin{array}{l}\text { Died of pulmon- } \\
\text { ary tubercle. }\end{array}$ \\
\hline 18 & , & Disobedient, unmanageable. & Improved. & - & Parkinsonian. \\
\hline 20 & , & $\begin{array}{l}\text { Emotional, dirty, morose, re- } \\
\text { sentful. }\end{array}$ & Unchanged. & 75 & Very backward. \\
\hline 21 & " & $\begin{array}{l}\text { Restless, bad temper, un- } \\
\text { controlled. }\end{array}$ & Unchanged. & 63 & 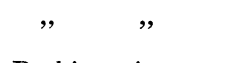 \\
\hline 23 & & Irritable, emotional. & Much improved. & - & Parkinsonian. \\
\hline 24 & , & Violent, sexually precocious. & Worse. & - & Very backward. \\
\hline 25 &. & Bad tempered, uncontrolled. & Quite good. & - & ? backward. \\
\hline 26 & , & Thieving, bad temper. & Improved. & - & Backward. \\
\hline 27 & , & Bad temper, unmanageable. & Not known. & - & \\
\hline 28 & ,. & Quarrelsome, cruel, dirty. & Improved. & 一 & Parkinsonian. \\
\hline 29 & , & Destructive, vicious, dirty. & Improved. & - & $\left\{\begin{array}{l}\text { Very backward. } \\
\text { Hyperpnœea. }\end{array}\right.$ \\
\hline 31 & & Rude, cruel. & Improved. & 56 & Very backward. \\
\hline 32 & , & Cruel, destructive, thieving. & Not traced. & - & . - \\
\hline 33 & , & Destructive. & Good. & - & Parkinsonian. \\
\hline 35 & $"$ & $\begin{array}{l}\text { Bad tempered, irritable and } \\
\text { quarrelsome. }\end{array}$ & Not traced. & - & - \\
\hline 37 & " & Irritable, destructive. & Improved. & 61 & Very backward. \\
\hline
\end{tabular}


TABLE XIV-continued.

('HANGE OF CONDUCT-continued.

\begin{tabular}{|c|c|c|c|c|c|}
\hline ('ase. & $\begin{array}{l}\text { Year of } \\
\text { acute } \\
\text { illness. }\end{array}$ & Change in Behaviour. & $\begin{array}{l}\text { ('onduct } \\
\text { at } \\
\text { present. }\end{array}$ & $\begin{array}{c}\text { Mental' } \\
\text { ratio. }\end{array}$ & General condition. \\
\hline 41 & 1922 & Bad tempered. & Unchanged. & 82 & $\left\{\begin{array}{l}\text { Parkinsonian. } \\
\text { Hyperpnoea. }\end{array}\right.$ \\
\hline 4.3 & 1923 & Quarrelsome, bad tempered. & Improved. & 80 & Backward. \\
\hline 44 &, & Cruel, destructive. & Improved. & 67 & Very backward. \\
\hline 45 & , & Irritable. & Improved. & $\ldots$ & Obese, lethargic. \\
\hline 46 & , & Irritable, forgetful. & Unchanged. & $\ldots$ & Backward. \\
\hline+7 &, & Bad tempered, cruel. & Good. & 93 & $\begin{array}{l}\text { Normal. } \\
\text { Very backward. } \\
\text { Mvoclonus, hy. }\end{array}$ \\
\hline $4 !$ & , & (Quarrelsone, unmanageable. & Enchanged. & 77 & $\left\{\begin{array}{l}\text { perpnoea, ac:- } \\
\text { commodation } \\
\text { lost. }\end{array}\right.$ \\
\hline 11 &. & Wild, violent, throws weapons. & Worse. & 73 & Parkinsonian. \\
\hline 52 & , & Bad tempered, quarrelsome. & Improving. & $87 \cdot 5$ & Parkinsonian. \\
\hline $5: 3$ & , & Wild, rude, restless. & Unchanged. & $\cdots$ & Very backward. \\
\hline$\pi 7$ & ", & $\begin{array}{l}\text { Untruthful, unmanageable, } \\
\text { destructive. }\end{array}$ & Unchanged. & 83 & $\begin{array}{l}\text { Restless and } \\
\text { backward. }\end{array}$ \\
\hline (i0 & 1924 & Bad tempered, violent. & Worse. & 102 & Hyperpnoea. \\
\hline (il & , & Irritable, bad tempered & Good. & 89 & Good. \\
\hline (6.) & , & Steals, cruel, bad tempered. & Worse. & - & Good. \\
\hline $6(j$ & , & Stealing, unmanageable. & Unchanged. & 62 & $\begin{array}{l}\text { Choreiform rest- } \\
\text { lessness. }\end{array}$ \\
\hline 70 & , & Bad tempered, violent. & Worse. & $87 \cdot 6$ & $\left\{\begin{array}{l}\text { Parkinsonian. } \\
\text { Myoclonus. }\end{array}\right.$ \\
\hline 72 & , & $\begin{array}{l}\text { Bad temper, cruel, quarrel- } \\
\text { some. }\end{array}$ & Improved. & 75 & Parkinsonian. \\
\hline 73 & " & $\begin{array}{l}\text { Bad temper, Hings knives, } \\
\text { spits. }\end{array}$ & Unchanged. & $7 \pi$ & $\left\{\begin{array}{l}\text { Parkinsonian. } \\
\text { Improving. }\end{array}\right.$ \\
\hline $7 \overline{1}$ & . & Bad tempered, cruel. & Enchanged. & 84 & Parkinsonian. \\
\hline 79 & 1925 & Stealing, disobedient. & Worse. & - & $\left\{\begin{array}{l}\text { Myoclonus. } \\
\text { Hyperpnoea. }\end{array}\right.$ \\
\hline 81 & 1926 & Irritable. & Enchanged. & 59 & $\left\{\begin{array}{l}\text { Restlessness. } \\
\text { Choreiform. }\end{array}\right.$ \\
\hline s:3 & , & ('ruel. destructive. & Enchanged. & -- & $\begin{array}{l}\text { Occasional noc- } \\
\text { turnal restless- } \\
\text { ness. }\end{array}$ \\
\hline
\end{tabular}

Apart from definite deterioration of character few children in the present series have been free of slighter changes. Almost all show an emotional reaction which was not present before, and few show normal shyness or reserve. In adult cases there appears to be frequently a continuously depressed attitude ; this has occurred in one child only. She is morose and resentful when brought to hospital and is said to be unwilling to enter into the family life at home. In all the others friendliness and cheerfulness are very noticeable. They are always willing to express regret for their misdeeds and to promise improved behaviour, although this does not prevent early and frequent repetition.

Prognosis as regards conduct changes. Auden ${ }^{33}$ found a gradual improve. ment in the behaviour and self-control of the larger number of his series of children, even where the conduct had been very bad. In the present series the prognosis as regards defects in behaviour is, on the whole, equally favourable.

The children whose acute illnesses occurred in the years 1918 to 1923 are, in the main, greatly improved in conduct, but there are still eight children, one dating back to 1919, whose behaviour is unchanged. In seven cases improvement in behaviour coincided with improvement in the time of sleep, and children who had been quite unmanageable became docile. In the majority, however, this had no effect. Where the acute illness was more recent, improvement is not so marked. 
Children who are suffering from a progressive Parkinsonian syndrome are sometimes reported to be improving in behaviour. In these, motor incapacity rather than real improvement may be producing the change.

Obesity.

This has occurred as a late manifestation in two cases, both girls. One of these had suffered from an acute choreiform attack, in 1920, followed by night restlessness. A year later abnormal increase in weight was noticed ai the same time as general immobility became apparent. Two years later she was very stout and lethargic, with the Parkinsonian syndrome well developed. She was not seen again till 1925 when she was found to be very emaciated and confined almost entirely to bed by extreme general immobility, tremor, festination and retropulsion which render walking impossible. Wimmer ${ }^{5}$ reports a similiar case.

\section{Other Systems.}

Bradycardia was present in two cases during the acute stage. In both it occurred during a period of very deep lethargy. In one it remained for four days; in the other for about two weeks. At the onset of the fall in the pulse rate in the second, the temperature rose to $102^{\circ}$, but the fever only lasted a few hours. Constipation was very severe in about 50 per cent. of the cases during the early weeks of illness. Labial herpes was present in the febrile stage in two cases. Filtz ${ }^{18}$ saw it frequently at this stage, but it has not often been reported by other observers.

\section{Prognosis in Epidemic Encephalitis.}

The prognosis as regards life in children affected by this disease appears trom this series to be fairly good. Only four, or 10 per cent., died during the acute stage. All these deaths occurred within the first sixteen days. Eight (10.5 per cent. of the children traced) died at varying periods after the acute illness. No one type of acute illness points in this series to a fatal result. The deaths during the acute stage occurred in two of the violently choreic type, in one of both chorea and lethargy, and in one purely lethargic case. A rectal temperature above $104^{\circ}$ was certainly of bad omen. The ages of the patients in whom death occurred in the acute stage were from 9 to 11 years, at which ages the disease was commonest. Of the eight who died in the later stages, four were under 13 months when acutely ill. Sex does not appear to have influenced the mortality. Seven of the eleven children who died were males, the same proportion as in the entire series.

Prognosis as regards survivors. Shrubsall:" in a series of 191 children. found that 13.6 per cent. make complete recoveries, Robb ${ }^{34} 5$ per cent., Nonne $^{35}$ found few definite cures in 161 cases. Grossman ${ }^{36}$, after intervals ranging up to 24 months, concluded that 70 per cent. had made good recoveries but on re-examination after intervals from one to three years found that only ten out of ninety-two cases were free of nervous symptoms.

In the present series sixty-five children are alive and have been examined recently. Of these only three are normal, both physically and mentally. One of the others, who was slow mentally and stunted in growth, has during the past year improved greatly and has recently been passed as suitable for the Territorial Force. 
In no case was recovery from the acute stage permanent. This period was in all cases brought to an end by the appearance of one or other of the sequelæ. The three children who now appear normal after periods of one year, eighteen months and two years respectively, all suffered from periods of nocturnal excitement and irritability between the apparent recovery following on the acute illness and the present improvement. The length of these periods makes it at least hopeful that these may eventually make complete recoveries. The fact that two of these have now regained the normal mental ratio for their age is also of good omen.

Of the remaining cases, one boy mentioned above earns a little money but is now deteriorating; several are in institutions, being beyond home management, and five are constantly in bed. The others with few exceptions are either in special schools or reported as incurable.

The most serious and most frequently progressive and crippling of the later manifestations is the Parkinsonian syndrome but mental deterioration is almost equally progressive. The other sequelæ tend, on the whole, towards im. provement.

\section{REFERENCES.}

1. Findlay, L., Glasgow Med. J., Glasg., 1918, XC, 193.

2. Findlay, L. and Shiskin, C., Ibid., 1921, XCV, 18.

3. Anderson, G. H., Quart. J. Med., Oxf., 1923, XVI, 173.

4. McAlpine, D., Proc. Roy. Soc. Med., Lond., 1923, XVI, Sect. Neur. 27.

5. Wimmer, A., Chronic Epidemic Encephalitis, Lond., 1924.

6. Walshe, F. M. R., Brain, Lond., 1920, XLIII, 197.

7. Sicard, J. A. \& Kudelski, C., Bull. et mém. Soc. mêd. d. hôp. de Paris, Paris, 1920, XLIV, $9 \dot{4}$.

8. Hall, A., Proc Roy. Soc. Med., Lond., 1925, XVIII, Sect. Neur., 17.

9. Marie, P., and Levy G., Rev. Neur., Paris, 1920, XXVII, 513.

10. Hinds Howell, C. M., Brit. Med., J., Lond., 1925, i, 437.

11. Stevenson, G. H., Loc. cit., 68.

12. Kennedy, R. J.,Amer. J. Dis. Child., Chic., 1924, XXVIII, 158.

13. Buzzard, E. F., Lancet, Lond., 1918, i, 616.

14. Souques, M. A., Rev. Neur., Paris, 1921, XXXVII, 559.

15. Cruchet, R., Lancet, Lond., 1925, ii, 263.

16. Sainton, P., and Schulmann, E., Rev. Neur., Paris, 1921, XXXVII, 1066.

17. Roger, H., Ibid., 1921, XXVIII, 677.

18. Piltz, J., Ibid., 1921, XXXVII, 793.

19. Von Economo, C., Wien. Klin. Woch., Vienna, 1917, XXX, 581.

20. Foster Moore, R., Medical Ophthalmology, Lond., 1922, 112.

21. Ministry of Health Report, 1922, No. 11.

22. Boveri, P., Rev. Neur., Paris, 1920, XXVII, 278.

23. Boveri, P., J. Neur. \& Ment. Dis., N.Y., 1920, LII, 328.

24. Symonds, C. P., Quart. J. Med., Oxf., 1921, XIV, 283.

25. Goodheart S. P. and Cottrell, S. S., J. Amer. Med. Ass., Chic., 1925, LXXXIV, 32.

26. Levy, G., Lancet, Lond., 1923, i., 241.

27. Hinds Howell, C. M., Brit. Med. J., Lond., 1923, ii, 1086.

28. Marie, P., Binet, P., and Levy, G., Bull. et mém. Soc. méd. d. hôp. de Paris, Paris, 1922, XLVI, 1075.

29. Shrubsall, P. C., Proc. Roy. Soc. Med., London, 1925, XVIII, Sect. Neur., 21.

30. Dawson, S., and Conn, J. C. M., Arch. Dis. Childhood, Lond., 1926, I, 357.

31. Hall, A. J., Brit. Med. J., Lond., 1925, i, 110.

32. Paterson, D., and Spence, J. C., Lancet, Lond., 1921, ii, 491.

33. Auden, G. A., Ibid., 1922, ii, 901.

34. Robb, A. G., Brit. Med. J., Lond., 1925, ii, 644.

35. Nonne, M., Cong. Int. Med., Vienna, Lancet, Lond., 1923, i, 866.

36. Grossmann, M., J. Amer. Med. Ass., Chic., 1922, LXXVIII, 959.

37. Genet, L., Lyon méd., Lyon, 1920, 721. 